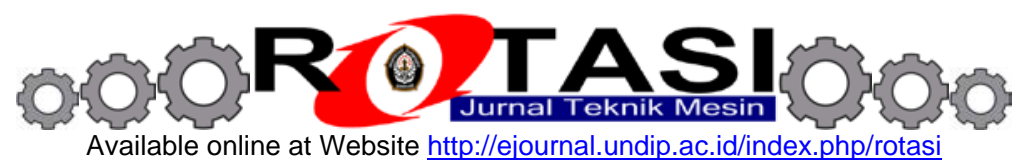

\title{
Studi Eksperimental Pengaturan Waktu Pengapian Pada Mesin 4 Langkah 1 Silinder Berbahan Bakar E25
}

\author{
*Arjuna Aji, Joko Triyono, Teguh Triyono \\ Jurusan Teknik Mesin, Fakultas Teknik, Universitas Sebelas Maret \\ Jl. Ir. Sutami No 36-A Kentingan Surakarta. Kode Pos, 57126. Telp, (0271) 646994. Fax, (0271) 646655 \\ *E-mail: arjuna.aji18@gmail.com
}

\begin{abstract}
Abstrak
The use of ethanol as a mixture of premium is for reducing dependency to the primuim, considering that premium is not renewable. The goal of the ethanol addition in a fuel is to increase the octane number. However the heating value of the ethanol is lower than premium, so it will decrease the performance of the SI engine. The study aimed for increasing the performance of SI engine using E25 as mixture of premium-ethanol. The performance of engine was measured by engine test bed on chassis. Change load method is used in the experiment. The experiments result is advancing the time of ignition at 4 degree that can improve the engine performance. The result of changes load use E25 fuel with advanced time of ignition at 4 degree can increase engine performance as torque, power, bmep, efficiency thermal and bsfc were decrease.
\end{abstract}

Kata kunci: change load, ethanol, engine performance, gasoline, time of ignition

\section{Pendahuluan}

Di Indonesia sebagian besar kendaraan bermotor berkerja menggunakan bahan bakar tak terbarukan. Penggunaan secara terus menerus tentunya akan dapat menghabiskan cadangan bahan bakar tersebut. Untuk mencegah hal tersebut perlu dilakukan penelitian mengenai penggunaan bahan bakar lain yang dapat diperbaharui. Salah satu bahan bakar alternatif yang dapat digunakan adalah dengan menggunakan etanol sebagai bahan bakar pengganti maupun campuran bahan bakar pada kendaraan bermotor.

Etanol merupakan bahan bakar terbarukan yang dapat dihasilkan dari fermentasi tanaman yang mengandung karbohidrat. Pencampuran etanol dapat menaikan nilai oktan bahan bakar, mengingat etanol mengandung 30\% oksigen, sehingga etanol dapat dikatagorikan sebagai high octane gasoline (HOG) [1]. Penambahan etanol mampu menciptakan pembakaran yang lebih sempurna, pada hal ini terbukti dengan penurunan nilai emisi gas buang CO dan peningkatan emisi CO2 [2]. Kalor laten penguapan etanol lebih tingingi 3-5 kali sehingga temperature pada intake manifold menjadi lebih rendah dan efisiensi volumetrik mesin menjadi lebih baik [3].

Selain keuntungan di atas, penggunaan etanol sebagai campuran bahan bakar memiliki beberapa kekurangan diantaranya nilai kalor etanol yang lebih rendah, sifat etanol yang dapat menyebabkan korosi pada sistem bahan bakar, etanol memiliki massa jenis yang berbeda dengan bahan bakar fosil dan mesin yang menggunakan campuran etanol akan sulit dinyalakan pada saat awal pengoperasian [4].

Penggaruh campuran bahan bakar bensin dan etanol terhadap unjuk kerja motor bakar bensin berdasarkan nilai kalor bahan bakar. Pengujian menggunakan variasi bahan bakar campuran premium dan etanol dengan komposisi campuran E0 (0\% etanol), E5 (5\% etanol), E15 (15\% etanol) dan E25 (25\% etanol). Hasil pengujian nilai kalor bahan bakar diperoleh nlai kalor premium 11.414,453 kal/gram; campuran etanol E5 = 8905,921 kal/gram; campuran E15 = 8717,552 kal/gram; campuran E25 = 8358,941 kal/gram. Hasil pengujian performa diperoleh daya tertinggi pada campuran E15 yaitu sebesar 9,02 kW. Hasil pengujian emisi gas buang diperoleh nilai CO terendah pada campuran E25 etanol yaitu 0,85\% volume udara; nilai CO2 tertinggi pada campuran E25 etanol yaitu 10,6\% volume udara [2].

Proses pembakaran yang terjadi terjadi lebih awal sebelum TC (Top Center) akan mengakibatkan tekanan langkah kompresi (dimana piston menekan udara dalam silinder) akan meningkat. Sebaliknya, jika proses pembakaran dimundurkan dengan cara menunda penyalaan busi maka tekanan tekanan maksimal hasil pembakaran akan menurun. Waktu pembakaran yang paling tepat untuk menghasilkan torsi secara maksimal dinamakan maximum brake torque atau MBT. Pemajuan waktu pengapian dipengaruhi dari beberapa aspek yaitu desain mesin, kondisi operasi mesin dan property dari bahan bakar, udara serta campuran gas pembakaran. Gambar 1. Menunjukan pengaruh variasi dari waktu pengapian terhadap torsi yang dihasilkan pada mesin SI [5].

Penelitian mengenai pengaruh variasi unjuk derajat pengapian terhadap kerja mesin. Pada derajat pengapian yang dimajukan dari standardnya, diperoleh peningkatan nilai prestasi pada mesin, dibanding drajat pengapian standard. Hal ini dapat dilihat dari nilai torsi dan daya poros yang lebih besar pada derajat pengapian yang dimajukan $6^{\circ}$ dari standarnya[6]. Peningkatan performa sepeda motor dengan variasi CDI (Capacitive Discharge Ignition) Programmable. Penelitian ini menyatakan bahwa dengan memajukan waktu pengapian CDI Programmable sebesar $2^{\circ}$ dari standarnya, daya mesin meningkat sebesar 0,2 HP dan torsi mesin meningkat sebesar 0,21 Nm [7]. 


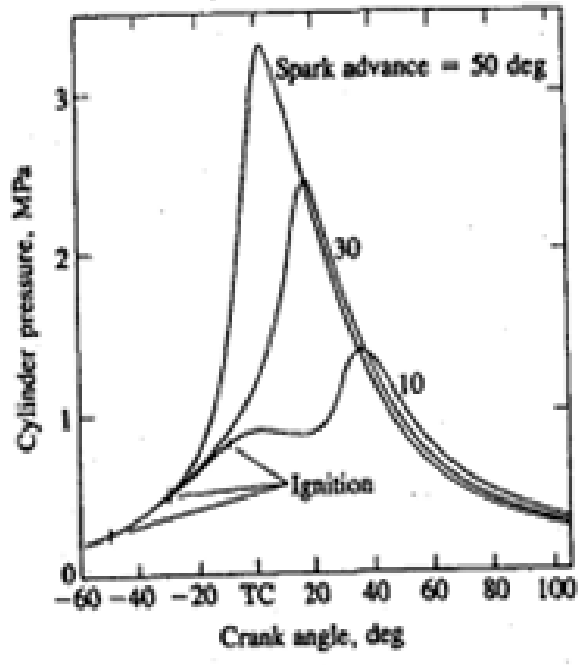

(a)

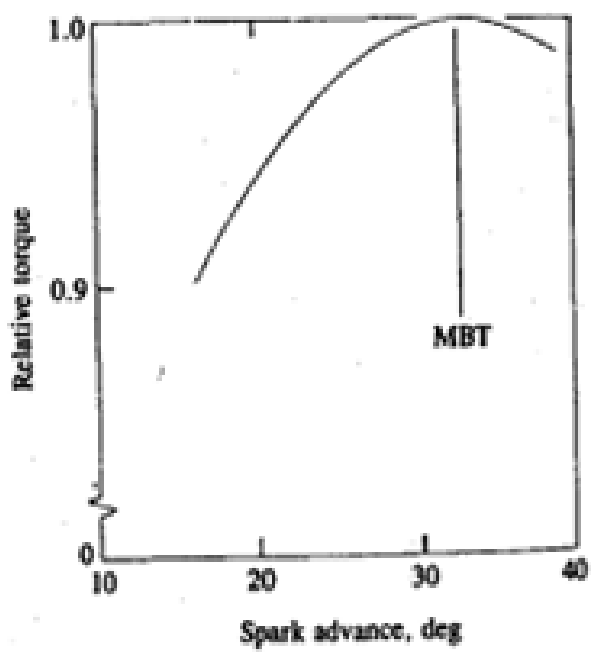

(b)

Gambar 1. (a) Tekanan silinder dengan sudut pengapian pada over advanced timing $\left(50^{\circ}\right)$, $\mathrm{MBT}$ timing $\left(30^{\circ}\right)$ dan retarded timing $\left(10^{\circ}\right)$. (b) Pengaruh pemajuan waktu pengapian pada brake torque [5].

Perbandingan variasi derajat pengapian terhadap efisiensi termal dan konsumsi bahan bakar otto engine BE50 (campuran bensin dan etanol dengan kadar etanol 50\%) [8]. Campuran bensin dan etanol memiliki peluang yang besar untuk digunakan sebagai bahan bakar mesin otto. Penelitian ini membahas tentang pengaruh dari variasi derajat pengapian terhadap efisiensi termal, konsumsi bahan bakar pada motor bensin. Penelitian menunjukan bahwa waktu pengapian opotimal bensin ada pada $9^{\circ}$ BTDC (Before Top Dead Centre) dan BE50 pada $12^{\circ}$ BTDC. Kinerja mesin berbahan bakar BE50 dibandingkan bahan bakar bensin menghasilkan SFC (Specific Fuel Consumtion) 4,06\%; nth 5,61\% dan EC turun 22,84\%.

Pengaruh waktu pembakaran pada unjuk kerja mesin dan emisi dari petrol engine. Pada mesin SI dengan memajukan waktu pengapian sebesar $4^{\circ}$ dapat meningkatkan torsi dan daya mesin. Dengan memajukan waktu pengapian tidak mempengaruhi emisi gas buang CO dan CO2. Waktu pembakaran yang terlalu mundur akan menyebabkan menurunya performa mesin dan meningkatkan emisi HC dan konsumsi bahan bakar [9].

Penelitian yang dilakukan bertujuan untuk mengetahui karakteristik mesin serta mencari waktu pengapian yang tepat pada mesin sepeda motor Honda Astrea Prima tahun 1998 menggunakan bahan bakar E25. CDI yang digunakan merupakan programmable CDI buatan PT. Rektor Technology Indonesia dengan tipe “Limited Edition”. Data yang didapat dari penelitian ini berupa data beban generator, puteran poros generator dan laju aliran bahan bakar. Dari data ini dianalisis untuk menentukan waktu pengapian yang ideal untuk bahan bakar E25 pada mesin untuk bahan bakar premium.

\section{Material dan metode penelitian}

Pengujian yang dilakukan menggunakan metode pengujian beban berubah atau full open throttle. Pegujian ini bertujuan untuk mengetahui unjuk kerja mesin secara maksimal. Dari pengujian yang dilakukan akan didapatkan data berupa nilai pembebanan pada generator, laju aliran bahan bakar dan putaran pada poros generator. Data tersebut digunakan untuk menghitung unjuk kerja mesin berupa torsi, daya poros, bmep (Brake Mean Effective Pressure), bsfc (Brake Specific Fuel Consumption) dan efisiensi termal.

Bahan bakar yang digunakan adalah premium dan campuran etanol-premium dengan kadar etanol 25\% (E25). Pada pengujian bahan bakar E25 sudut pengapian yang digunakan yaitu sudut pemgapian standar, sudut pengapian standar $+2^{\circ}$, sudut pengapian standar $+4^{\circ}$ dan sudut pengapian standar $+6^{\circ}$. Variasi sudut pengapian diperoleh dengan cara menganti CDI standar dengan CDI Programmable. Pengukuran unjuk kerja mesin dilakukan dengan menggunakan dinamometer jenis engine test bed on chassis seperti yang terlihat pada Gambar 2.

Proses pengujian diawali dengan mempersiapkan semua alat yang akan digunakan. Persiapan alat diantaranya adalah memeriksa kondisi oli mesin, tegangan pada tali tie down, posisi motor, posisi blower, tekanan pada ban belakang sepeda motor, pemasangan tachometer pada sepeda motor dan memeriksa pengait pada neraca pegas di lengan generator. Selain pemeriksaan alat dilakukan juga pengkalibrasian alat seperti pada tachometer, burret, neraca pegas dan multimeter. Persiapan bahan dilakukan dengan memeriksa ketersediaan bahan bakar premium dan etanol serta membuat campuran bahan bakar E25. 


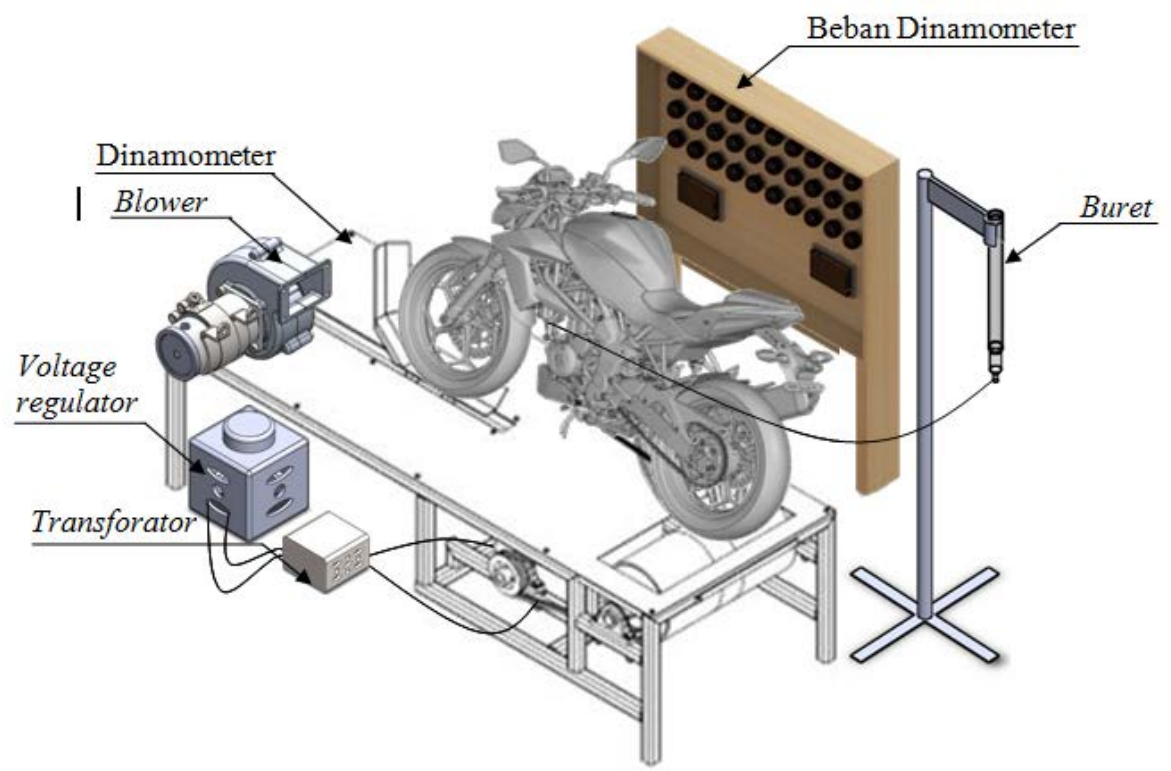

Gambar 2. Engine test bed on chassis

Pengujian yang dilakukan menggunakan gear ratio 3. Pengujian ini diawali dengan mengkondisikan bukaan gas pada posisi full throattle yang kemudian dilakukan pembebanan hingga didapatkan putaran mesin 9000 rpm. Setelah mesin mencapai putaran tersebut dilakukan pengambilan nilai pembebanan pada generator. Langkah selanjutnya dilakukan dengan mengukur putaran poros pada dinamometer. Pada saat yang sama, dilakukan juga pencatatan waktu yang dibutuhkan untuk menghabiskan $10 \mathrm{ml}$ bahan bakar. Setelah selesai dilanjutkan dengan mengubah putaran mesin menjadi 8000 rpm hingga 4000 rpm dengan selisih pengambilan data pada setiap $1000 \mathrm{rpm}$.

Motor yang digunakan adalah motor Honda Astrea Prima yang diproduksi pada tahun 1989 dengan spesifikasi sebagai berikut:

Tipe mesin : 4 Langkah, SOHC 2 Valve

Silinder : Single

Bore $x$ Stroke : 50 x 49,5 mm

Kompresi : 9

Pendingin : Udara

Transmisi : 4-speed (N-1-2-3-4)

Battery :12V-4Ah

Busi : C7HSA/ U 22 FS-U

Pengapian : CDI-AC berikut:

Bilangan oktan pada pencampuran beberapa jenis bahan bakar dapat dihitung dengan persamaan 1 sebagai

$$
\mathrm{ON}_{\operatorname{mix}}=(\% \circ \mathrm{A})(\mathrm{ONA})+(\% \circ \mathrm{B})(\mathrm{ON} \mathrm{B})
$$

Persamaan rumus yang digunakan untuk mendapatkan nilai unjuk kerja mesin adalah sebagai berikut:

a. Torsi dan daya

Torsi didefinisikan sebagai gaya kerja sepanjang moment. Torsi merupakan ukuran kemampuan kerja suatu mesin. Torsi yang dihasilkan oleh mesin dapat diukur menggunakan torquemeter yang dikopel dengan poros output suatu mesin. Torsi yang dapat dihasilkan suatu mesin bisa dihitung dengan persamaan 2 sebagai berikut:

$$
\text { Torsi }=\mathrm{F} \times \mathrm{b}
$$

Oleh karena sifat dinamometer yang bertindak seolah-olah seperti sebuah rem dalam sebuah mesin maka daya yang dihasilkan keluaran poros ini sering disebut sebagai bp (brake power) sedangkan daya yang terjadi pada ruang bakar disebut daya indikatif atau ip (indicative power). Untuk menghitung $b p$ yang dikeluarkan oleh poros dapat dihitung menggunakan persamaan 3 sebagai berikut:

$$
\bar{b} p=2 \pi \times \mathrm{N} \times \mathrm{T} / 60
$$


b. Tekanan efektif rata-rata

Tekanan didalam silinder pada suatu mesin berubah secara terus menerus sepanjang siklus. Sebaliknya dapat dicari harga tekanan tertentu yang konstan yang apabila mendorong torak sepanjang langkahnya dapat menghasilkan kerja persiklus yang sama dengan siklus yang dianalisis. Tekanan ini dinamakan tekanan efektif rata-rata rem atau brake mean effective pressure ( $(\mathrm{m} e \mathrm{ep}$ ). Besar bmep dirumuskan dengan persamaan 4 sebagai berikut:

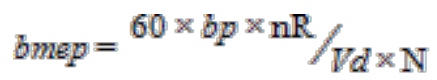

c. Konsumsi bahan bakar spesifik

Konsumsi bahan bakar spesifik atau brake specific fuel consumption (bsfc) didefinisikan sebagai jumlah bahan bakar yang dikonsumsi per satuan daya per jam operasi. Nilai bsfc dapat dihitung dengan persamaan 5 dan 6 sebagai berikut:

$$
\begin{aligned}
& \tilde{b s f c}={ }^{\tilde{m} f} / \delta p \\
& \tilde{m} f=V_{/ \mathrm{t} \times \mathrm{p}}
\end{aligned}
$$

\section{d. Efisiensi termal}

Efisiensi termal suatu mesin didefinisikan sebagai perbandingan kerja yang dihasilkan oleh mesin dengan energi yang masuk dari pembakaran bahan bakar di dalam silinder. Efisiensi termal dapat dirumuskan dengan persamaan 7 sebagai berikut:

$$
\eta_{t}={ }^{P} / \tilde{m f} \times Q_{H V}
$$

Bab ini berisi tentang data-data penting penelitian, peralatan yang digunakan dan lokasi penelitian. Metode penelitian yang digunakan dijelaskan secara singkat (dapat dibuat dalam bentuk diagram alir). Metode baru atau metode yang dimodifikasi tersebut harap dijelaskan secara rinci.

\section{Hasil dan pembahasan}

\subsection{Penguian bahan bakar}

Pengujian bahan bakar dilakukan di Laboratorium Teknologi Minyak Bumi, Gas dan Batubara UGM. Bahan bakar diuji untuk mengetahui nilai specific gravity dan gross heating value.

Tabel 1. Hasil uji bahan bakar

\begin{tabular}{ccccc}
\hline \multirow{2}{*}{ No. } & \multirow{2}{*}{ Jenis Pemeriksaan } & Satuan & \multicolumn{2}{c}{ Hasil Pemeriksaan Kode Sempel } \\
\cline { 3 - 5 } & & & Premium & E25 \\
\hline 1 & Specific Gravity at $60 / 60^{\circ} \mathrm{F}$ & g & 0,7421 & 0,7592 \\
\hline 2 & Gross Heating Value & BTU/lb & 20300,0 & 20141,3 \\
\hline
\end{tabular}

Dari Tabel 1 dapat dilihat perbedaan nilai kalor dan specific gravity pada bahan bakar premium dan E25. Pengujian nilai kalor bahan bakar diperlukan untuk menghitung nilai efisiensi termal mesin pada variasi bahan bakar yang digunakan. Semakin besar kadar etanol pada campuran bahan. Pengujian nilai specific grafity diperlukan dalam perhitungan dalam mencari nilai konsumsi bahan bakar spesifik pada mesin. Bilangan oktan dari bahan bakar E25 dapat diprediksi sebesar 93,5 dengan menggunakan persamaan 1 sebagai berikut:

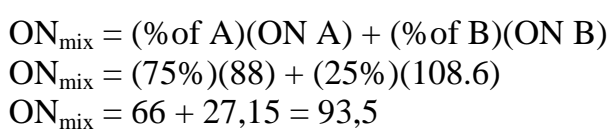

\subsection{Unjuk kerja mesin Honda Astrea Prima}

\subsubsection{Torsi}

Gambar 3 menunjukan perbedaan nilai torsi pada semua variasi yang digunakan terhadap putaran mesin. Torsi maksimum mesin tercapai pada putaran mesin $6000 \mathrm{rpm}$ untuk semua variasi yang diujikan. Torsi mesin dengan bahan bakar premium mencapai nilai torsi maksimal sebesar $4.82 \mathrm{Nm}$, sedangkan untuk bahan bakar E25 dengan variasi sudut pengpian standar adalah $4,69 \mathrm{Nm}$. Variasi E25 sudut pengapian standar $+2^{\circ},+4^{\circ}$ dan $+6^{\circ}$ torsi maksimal mesin dicapai sebesar $5.22 \mathrm{Nm}$; 5,28 $\mathrm{Nm}$ dan 4,95 Nm. 


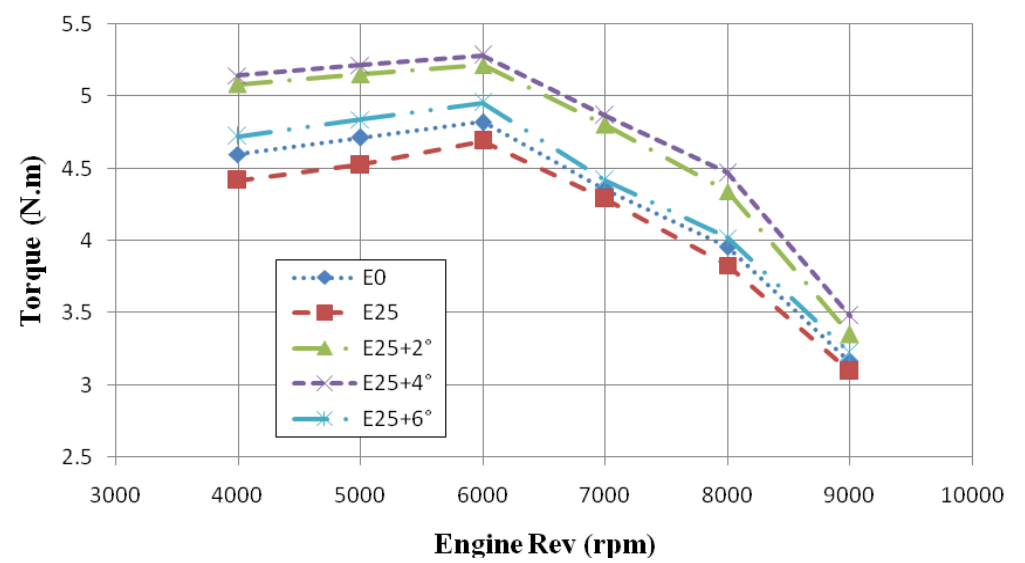

Gambar 3. Grafik torsi

\subsubsection{Daya poros}

Gambar 4 menunjukan grafik hubungan daya poros dengan putaran mesin disetiap variasi yang digunakan. Nilai daya tertinggi pada variasi bahan bakar premium sudut pengapian standar yaitu 4,4396 kW, sedangkan daya yang diperoleh pada variasi bahan bakar E25 sudut pengapian standar, E25 sudut pengapian standar $+2^{\circ}$, E25 sudut pengapian standar $+4^{\circ}$ dan E25 sudut pengapian standar $+6^{\circ}$ berturut-turut yaitu 3,95 kW; 4,87 kW; 5,01 kW dan 4,51 $\mathrm{kW}$.

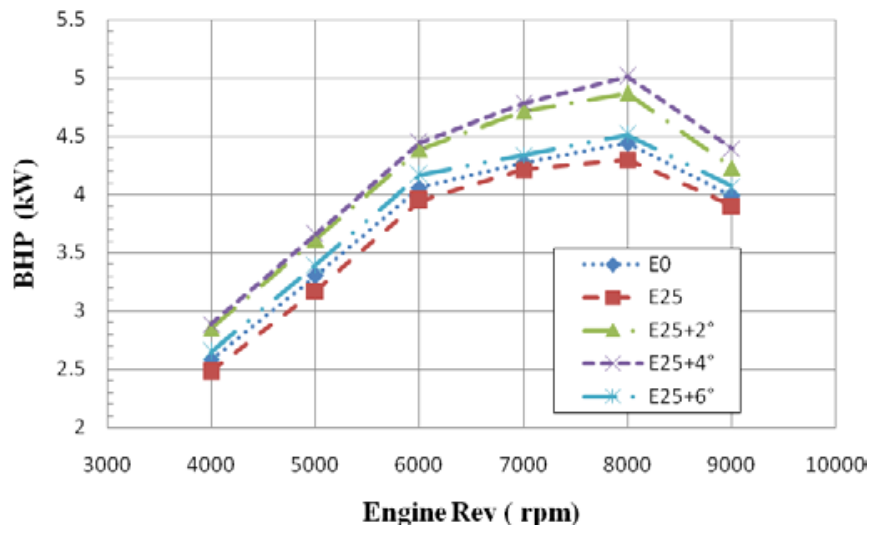

Gambar 4. Grafik daya poros

\subsubsection{Tekanan efektif rata-rata}

Gambar 5 menunjukan perbedaan tekaan efektif rata-rata pada setiap putaran mesin. Nilai bmep terbesar dari variasi bahan bakar premium sudut pengapian standar, E25 sudut pengapian standar, E25 sudut pengapian standar $+2^{\circ}$, E25 sudut pengapian standar $+4^{\circ}$ dan E25 sudut pengapian standar $+6^{\circ}$ berturut-turut adalah $605,49 \mathrm{kPa}$; $588,90 \mathrm{kPa}$; 655,25 kPa; 663,55 kPa; 622,08 kPa pada $6000 \mathrm{rpm}$.

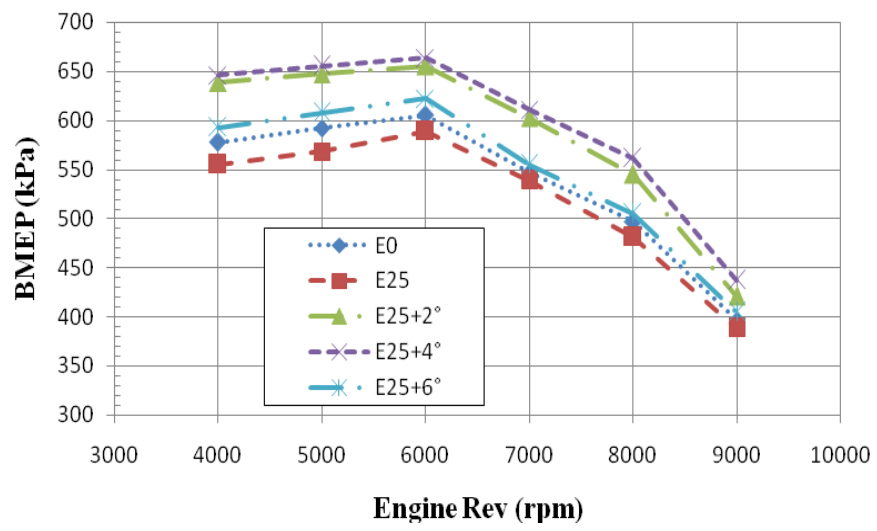

Gambar 5. Grafik tekanan efektif rata-rata 


\subsubsection{Konsumsi bahan bakar spesifik}

Gambar 6 menjelaskan tentang hubungan konsumsi bahan bakar spesifik ( $b s f c)$ dengan putaran mesin pada setiap variasi pengujian. Nilai $b s f c$ tertinggi diperoleh pada putaran mesin 9000 rpm untuk semua variasi yang diujikan. Nilai $b s f c$ tertinggi dari variasi bahan bakar premium, E25 pengapian standar, E25 sudut pengapian standar $+2^{\circ}$, E25 sudut pengapian standar $+4^{\circ}$ dan E25 sudut pengapian standar $+6^{\circ}$ berturut-turut adalah 0,60 kg/kW.h;0,65 kg/kW.h; 0,55 kg/kWh; 0,52 kg/kW.h dan $0.58 \mathrm{~kg} / \mathrm{kW} . \mathrm{h}$ pada $9000 \mathrm{rpm}$.

Nilai $b s f c$ terendah dicapai pada Nilai $b s f c$ terendah dicapai pada $6000 \mathrm{rpm}$ pada semua variasi yang diujikan. Nilai $b s f c$ terrendah dari variasi bahan bakar premium sudut pengapian standar, bahan bakar E25 pengapian standar, E25 sudut pengapian standar $+2^{\circ}$, E25 sudut pengapian standar $+4^{\circ}$ dan E25 sudut pengapian standar $+6^{\circ}$ berturut-turut adalah 0,$42 ; 0,45 ; 0,38 ; 0,36$ dan 0,41 .

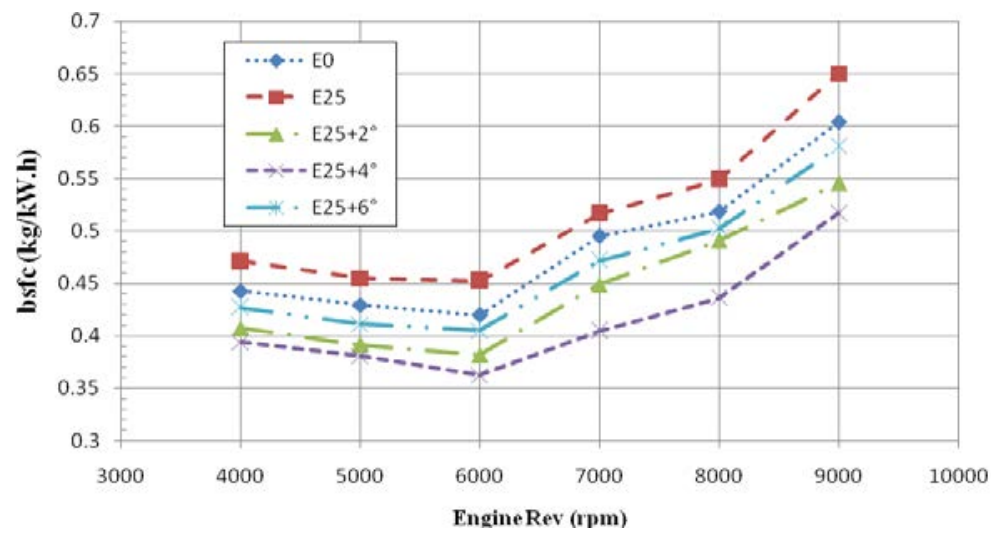

Gambar 6. Grafik konsumsi bahan bakar spesifik

\subsubsection{Efisiensi termal}

Hasil perhitungan efisiensi termal pada semua variasi yang diujikan dapat dilihat pada Gambar 7. Nilai efisiensi termal tertinggi dicapai pada $6000 \mathrm{rpm}$ untuk semua variasi yang diujikan. Nilai efisiensi termal tertinggi dari variasi bahan bakar premium sudut pengapian standar, bahan bakar E25 pengapian standar, E25 sudut pengapian standar $+2^{\circ}$, E25 sudut pengapian standar $+4^{\circ}$ dan E25 sudut pengapian standar $+6^{\circ}$ berturut-turut adalah $18,17 \% ; 17 \%$; 20,15\%; $21,20 \%$ dan $18,98 \%$.

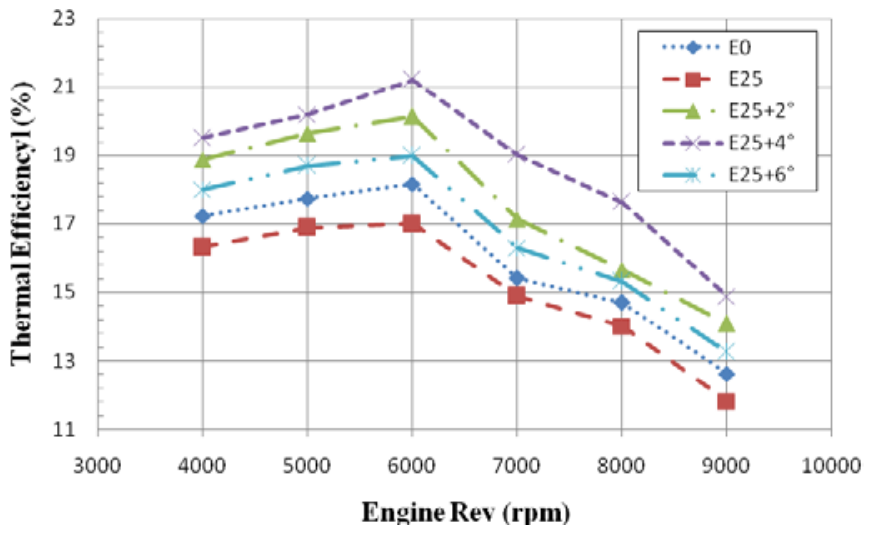

Gambar 7. Grafik efisiensi termal

\subsection{Pembahasan dan Diskusi}

Dari hasil pengujian bahan bakar dapat dilihat bahwa nilai kalor bahan bakar E25 lebih rendah dari pada premium. Penggunaan bahan bakar yang memiliki nilai kalor yang lebih rendah dapat mengakibatkan meurunya performa mesin [10]. Hal ini dibuktikan pada hasil perhitungan performa mesin dengan menggunakan sudut pengapian yang sama, mesin yang menggunakan bahan bakar E25 memiliki performa mesin yang lebih rendah dibandingkan mesin yang menggunakan bahan bakar premium.

Bahan bakar E25 memiliki bilangan oktan lebih besar dibandingkan dengan premium. Bilangan oktan yang lebih besar menandakan bahan bakar akan lebih sulit terbakar, sehingga bahan bakar memerlukan waktu yang lebih lama dalam proses pembakaranya. Kadar air yang tinggi pada etanol jika dicampurkan pada bahan bakar premium akan 
memengaruhi kecepatan pembakaran. Hal ini disebabkan oleh uap air pada etanol akan menyerap panas yang menyebabkan berkurangnya kecepatan pembakaran yang terjadi pada ruang bakar [11].

Penggunaan bahan bakar E25 memperlukan waktu pembakaran yang lebih lama untuk menyelesaikan proses pembakaran, namun tekanan pembakaran maksimal dari proses pembakaran harus tetap terjadi pada posisi piston mencapai $5^{\circ}$ samapi $10^{\circ}$ setelah TMA. Ketentuan tersebut mengharuskan proses pada mesin yang menggunakan bahan bakar E25 harus dilakukan lebih maju dari penggunaan bahan bakar premium.

Hasil perhitungan performa mesin mengambarkan bahwa mesin yang menggunakan bahan bakar E25 dengan sudut pengapian yang lebih maju akan meningkatkan performa mesin tersebut. Akan tetapi pada variasi bahan bakar E25 dengan sudut pengapian standar $+6^{\circ}$ terjadi penurunan performa mesin. Hal ini dikarenakan sudut pengapian yang terlalu maju atau over advance sehingga tekanan puncak yang dihasilkan dari proses pembakaran terjadi pada saat posisi piston belum mencapai $5^{\circ}$ setelah TMA [12].

Dari semua variasi pengujian, bahan bakar E25 dengan sudut pengapian standar $+4^{\circ}$ memiliki performa mesin yang paling maksimum. Hal ini disebabkan karena dengan memajukan sudut pengapian sebesar $4^{\circ}$ dari sudut standarnya tekanan maksimal hasil pembakaran terjadi pada saat yang tepat, sehingga sebagian besar energi yang terkandung dalam bahan bakar dapat diubah menjadi tenaga pendorong piston.

\section{Kesimpulan}

Hasil pengujian performa mesin menunjukana penggunaan bahan bakar E25 dengan sudut pengapian standar pada motor Honda Astrea Prima dengan kapasitas silinder 100 cc berdampak pada menurunnya output torsi mesin, daya mesin, tekanan efektif rata-rata dan efisiensi termal mesin, dengan menurunya output mesin maka konsumsi bahan bakar spesifik akan mesin menjadi lebih besar. Penggunaan sudut pengapian standar $+4^{\circ}$ merupakan sudut pengapian yang tepat untuk digunakan pada mesin dengan bahan bakar E25. Sudut pengapian standar $+4^{\circ}$ mampu meningkatkan unjuk kerja mesin secara keseluruhan. Pada sudut pengapian ini, unjuk kerja mesin memiliki performa yang lebih baik dari pada bahan bakar premium. Hal ini di tunjukan dengan meningkatnya output torsi mesin, daya poros, tekanan efektif rata-rata dan efisiensi termal yang dihasilkannya. Selain itu, nillai konsumsi bahan bakar spesifik mengalami penurunan seiring dengan meningkatnya unjuk kerja mesin.

\section{Referensi}

[1] Wahid, M.A., 2005. Pemanfaatan Bio-Etanol Sebagai Bahan Bakar Kendaraan Berbahan Bakar Premium, Jurnal Prospek Pengembangan Bio-Fuel sebagai Substitusi Bahan Bakar Minyak Vol.2 No.2

[2] Agrariksa, F.A., Susilo, B., Nugroho, W.A., 2013. Uji Peformasi Motor Bakar Bensin (On Chasis) Menggunakan Campuran Premium dan Etanol, Jurnal Keteknikan Pertanian Tropis dan Biosistem Vol.1, No. 3, 194-203

[3] Yuksel, F., dan Yuksel, B., 2004. The use of Ethanol-gasoline blend as a fuel in an SI engine, Turkey: fakulty of engineering, Department of Mechanical Engineering, University of Ataturk.

[4] Setyawan, A., 2012. Kajin Eksperimental Pengaruh Etanol Pada Premium Terhadap Karakteristik Pembakaran Kondisi Atmosferik Dan Bertekanan Di Motor Otto Silinder Tunggal Sistem Injeksi, T.A., Fakultas Teknik Program Studi Teknik Mesin. Depok

[5] Heywood, J.B., 1988. Internal Combustion Engine Fundamental, McGraw-Hill Book Company. USA

[6] Syahril, M., Untoro B.S., Leydon S., 2013. Pengaruh Variasi Unjuk Derajat Pengapian Terhadap Kerja Mesin, Jurnal Teknik Vol.3 No.1/APRIL2013. ISSN 2088-3676

[7] Siswanto, I. dan Efendi, Y., 2015. Peningkatan Performa Sepeda Motor dengan Variasi CDI Programmable, Jurnal Science Tech LP2M UST Yogyakarta Vol 1 No 1.

[8] Nanlohy, H.Y., 2012. Perbandingan Variasi Derajat Pengapian Terhadap Efisiensi Termal Dan Konsumsi Bahan Bakar Otto Engine Be50, Jurnal Dinamika Vol. 3 No. 2 Mei 2012, Fakultas Teknik Universitas Halueleo. Kendari

[9] Sadiq, Y.R., 2016. A Study on Influence of Ignition Timing on Performance and Emission of Petrol Engine. Global Jurnal For Research analysis Volume-5, Issue-2, Feb-2016. ISSN N0 2277-8160

[10] Wiratmaja, I.G., 2010. Analisa Unjuk Kerja Motor Bensin Akibat Pemakaian Biogasoline, Jurnal Ilmiah Teknik Mesin, Vol. 4 No. 1

[11] Suarta, I.M., 2012. Pengaruh Kadar Air Pada Etanol Terhdap Kecepatan Pembakaran Dalam Hele Shaw Cell, Jurnal Matrix Vol. 2, No. 1 Maret 2012

[12] Pulkrabek, W.W., 1997. Engineering Fundamentals of the Internal Combustion Engine, Prentice Hall. Upper Saddle River - New Jersey 07458 